\title{
Natural Gas Fermentation: A Promising Approach for Sustainably Meeting the World's Growing Nutritional Demands
}

\author{
Adel M. Al Taweel \\ Department of Process Engineering and Applied Sciences, Dalhousie University, Halifax NS, \\ CANADA
}

e-mail: al.taweel@dal.ca

\begin{abstract}
The rapid increase in world population, combined with the rising expectation for more nutritional diets in many rapidly developing economies, is creating a strong demand for the protein-rich materials used for human consumption and/or animal feed. Meeting such a demand is already exerting significant pressure on the environment and creating significant pressure for identifying and implementing more sustainable approaches for protein production and utilization. This looming problem needs to be addressed quickly, considering the recent accelerating rise in feed and food prices and their subsequent impact on the sociopolitical stability of several developing societies. This paper quickly reviews the environmental impact of current practices used for meeting the world's protein needs. It then introduces an environmentally-friendly novel approach for converting natural gas into Single Cell Protein that can be used as an ingredient in animal feed formulations. After reviewing the historical background for this approach and the various factors affecting its sustainability, the main impediments to its widespread adoption are discussed, and several means for enhancing the overall sustainability of the approach are presented.
\end{abstract}

Index terms: Demand for nutritious food; Enhancing sustainability potential; Environmental impact; Single Cell Protein;

\section{INTRODUCTION}

Over the past century, the food production pattern across the world has undergone a radical change as a result of adopting large-scale, intensive agricultural production practices. The increased efficiency of such systems led to reducing the prices for many daily necessities and helped to reliably nourish a rapidly growing population. For example, with an increase of just $10 \%$ in the agricultural land area used, the global food production doubled [1]. This, in turn, led to a significant increase in the global consumption of various sources of animal-based protein (e.g. Fish, Poultry, lamb/goat, beef), which is driven by the increase in the world's population, as well as the rising nutritional expectations throughout the world (Figure1). However, as shown in Figure 2, there is a very large disparity in meat production/consumption patterns throughout the world, where meat supply has grown in most of the world's regions [2]. However, the very efficient and cost-effective modern transportation system played a significant role in balancing the rapidly changing demand/production balance throughout the world.

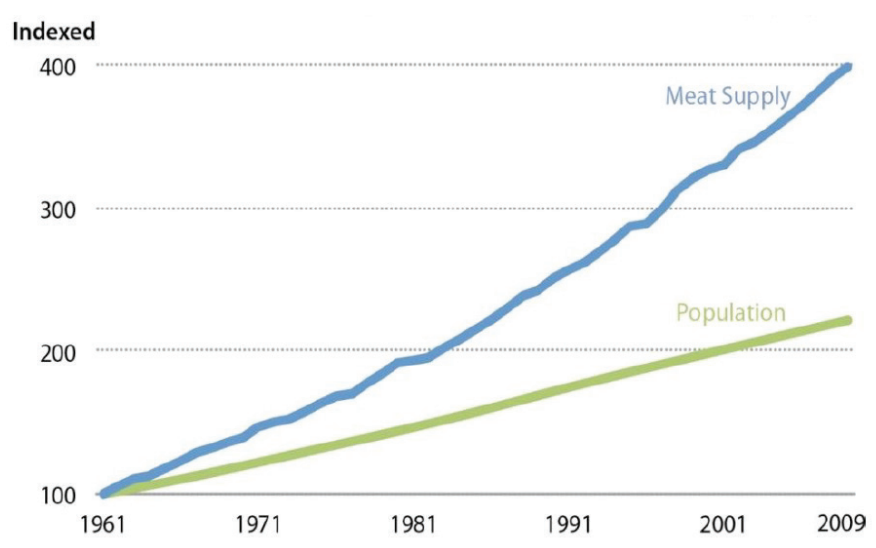

Fig. 1. Growth of the world's population and meet supply, Indexed $1961=100[2]$.

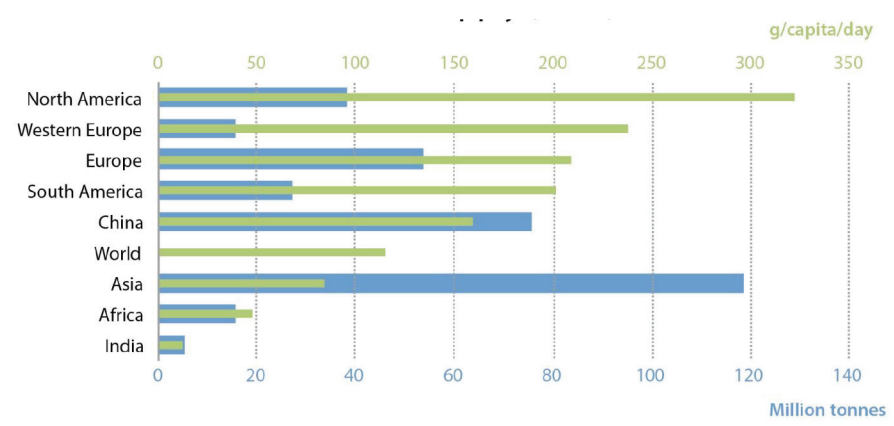

Fig. 2. Regional disparity in the total and per capita meat supply and consumption [2]. 
As can be seen from Figure 3, there is a strong link between the per capita meat consumption and the level of income in many countries of the world, with the effect of increased income on diets being most pronounced among lower- and middle-income populations.

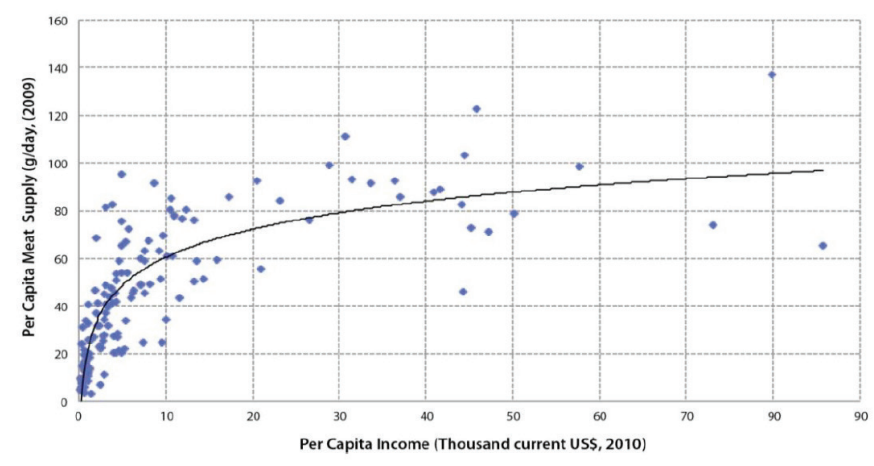

Fig. 3. Relationship between the level of income and the per capita meat consumption [2].

Finally, not only has the per capita meat consumption grown throughout the world but there are also, presently, many more consumers of meat and meat products. For example, the global human population grew from around 5 billion in 1987 to about 7 billion in 2011 and is expected to reach 10 billion people in 2050.

\section{ENVIRONMENTAL IMPACT OF PROVIDING NUTRITIOUS FOOD TO THE WORLD}

The rapid increase in the world's population, combined with the growing demand for improved nutrition in many developing countries, resulted in the projected global food demand to double by 2050. Unfortunately, a significant portion of the feed, food grains and oilseeds are being diverted into biofuels, resulting in critical pressures on suppliers worldwide. The recent rise in feed and food prices is but an example of the increased competing demands.

It exemplifies the need to consider unconventional sustainable approaches for food production that allow people to have physical, social, and economic access to sufficient and nutritious food that meets their dietary needs for a healthy and active life.

The deficiency is even greater in the case of protein, an essential nutrient in human health. Therefore, meeting such a demand is projected to exert significant pressures on the environment unless unconventional sustainable approaches for protein production are identified and developed. For example, the greenhouse gas, GHG, emissions from global livestock are estimated to already be larger than those emanating from all forms of transport (7.1 Gigatonnes of CO2-equivalent per year, representing 14.5 percent of all anthropogenic GHG emissions), with cattle being responsible for about $65 \%$ of the emissions [2-8].

Furthermore, several studies estimated that 70-80\% of the water footprint caused by human activities is associated with agricultural activities. Future trends are even more worrisome. For example, whereas the global GHG emissions associated with agricultural activities grew by $8 \%$ in the period between 1990 and 2010 , they are expected to grow further by $15 \%$ above 2010 levels by 2030. Furthermore, it is anticipated that the rise in agriculturally related GHG emissions will be particularly acute across Asia and sub-Saharan Africa since these two areas will account for around two-thirds of the increase in food demand over the first half of the 21st century. In addition, there are growing public health implications associated with livestock production and the magnitude of problems arising from the emergence of novel diseases at the animal-human-ecosystems interface.

One of the major causes of the aforementioned environmental impacts associated with Intensified Farm Animal Production (IFAP) is the large energy and resource inputs required for this type of production (including feed production and transport) and the enormous amounts of animal waste that is being produced in a very small area. For example, the USDA Agricultural Research Services estimated that the manure output from farm animals in the United States to be nearly 1 million tons of dry matter per day, of which $86 \%$ was estimated to be produced by animals held in confinement.

This heavy impact emanates from the following factors [5], where the impact of the various animal species is strongly influenced by the efficiency by which they can convert the nutrients present in the animal feed to meat:

- Methane from enteric fermentation,

- Nitrous oxide (N2O) from excreted nitrogen, as well as from the synthetic nitrogenous fertilizers used to produce the animal feed.

- Misuse of water resources,

- Accelerated biodiversity loss

- Uncontrolled discharge of fertilizers and pesticides

- Deforestation resulting from the need for additional arable land to produce animal feed.

A significant reduction in the environmental impacts associated with meat consumption may be achieved by reducing the amount of wastage in the food supply chain and using more resource-efficient avenues for producing the proteins needed for human and animal growth $[6,9]$. The latter approach is usually quantified using the feed conversion ratio, FCR, which is a measure of the efficiency with which the bodies of livestock convert animal feed into the desired output. 
For animals raised for meat (such as beef cows, pigs, chickens, and fish), the output is the flesh or the body mass gained by the animal, represented either in the final mass of the animal or the mass of the dressed output. FCR is thus the mass of the input divided by the output (thus mass of feed per mass of meat) and can differ significantly between different animals and species:

- Compared with other livestock, ruminants have relatively poor FCR values. For beef cattle, in the USA, an FCR calculated on live weight gain can vary between $4.5-7.5$, with the normal typical FCR value being above 6 .

- $\quad$ On the other hand, commercial pigs had FCR values that vary between 3.5 and 4.1 depending mainly on their weight at slaughter.

- $\quad$ For sheep, the FCR values vary between 5 and 6 depending mainly on their age and the quality of the feed used.

- $\quad$ From the early 1960s to 2011 in the US, broiler growth rates doubled, and their FCRs halved, mostly due to improvements in genetics and rapid dissemination of the improved chickens. Consequently, the global average FCR is around 2.0 based on live weight and 2.8 based on the slaughtered meat weight.

- The best FCR are encountered in aquaculture, where Atlantic salmon and catfish had an FCR of around 1, while tilapia is about 1.5.

The factors mentioned above constitute severe challenges to achieving food and nutrition security and led to the emphasis being placed on developing new food production systems that incorporate "improved public health and welfare" as one of the main factors taken into consideration. The concept of "Sustainable Diet" advocates adopting a diet with a reduced environmental impact that can simultaneously contribute to the elimination of poverty, food and nutrition insecurity, and poor health outcomes [10]. This concept is very similar to the "Climate-Smart Agriculture" concept advocated by FAO in which the system fights climate changes while simultaneously enhancing food security, as both are closely related [11].

Several investigators and agencies have proposed the implementation of positive and negative carbon taxes to achieve those goals. In this approach, the emission intensities of different meat products are taken into consideration when applying a carbon tax [12]. However, such measures need to be cautiously evaluated before implementation to unnecessarily disturb the demand/supply balance for such a critical commodity.

Since the feed costs presently constitute the major production cost factors for all livestock operations, market forces have already played a significant role in promoting the marketing, and consumption, of livestock that can efficiently convert animal feed into animal meat (e.g. poultry and fish). This is highlighted by the staggering growth in demand for poultry in South East Asia (in excess of a 7-fold increase between 2000 and 2030), which is primarily attributed to increasing per capita consumption rates rather than increasing population levels [13] as well as in the strong rise demand for fish products discussed below.

Similarly, seafood consumption is generally increasing in many parts of the world and is widely promoted as part of a healthy diet. Fish meat has a higher protein content compared to terrestrial animal meat, and fish have a lower feed conversion rate FCR than land animals. More protein can thus be produced by growing fish at lower feed rates. Furthermore, fish protein is highly digestible and rich in essential amino acids (including methionine and lysine), which are limited in animal-sourced protein.

However, food safety risks such as heavy metal content could be of concern, particularly with contaminated, wild fish. Negative social outcomes are also associated with aquaculture in countries where there are weak regulatory frameworks, and there is concern about the possibility of emerging diseases and disease transmission due to increased intensification and globalization.

\section{AQUACULTURE CONTRIBUTION TOWARDS MEETING THE WORLD'S PROTEIN DEMAND: ENVIRONMENTAL IMPACT}

As shown above, the global demand for high-quality protein-rich foods will continue to increase as the global population grows and as the nutritional demands in the rapidly developing countries accelerate. This is clearly shown in Figure 4, where the capture fisheries reached a peak around 1988, whereas, with its very good feed conversion factors, aquaculture has grown exponentially over the past three decades to fulfill some of the demand.

It is presently the fastest-growing animal protein industry. However, despite the increased output from global aquaculture, farming of marine fishes is unlikely to overtake marine capture production in the near future [14]. Furthermore, the contribution of non-fed aquaculture declined from $44 \%$ in 2000 to about $30 \%$ percent in 2018 . That trend is expected to be accelerated by the development of low-cost, environmentally-friendly feed. 


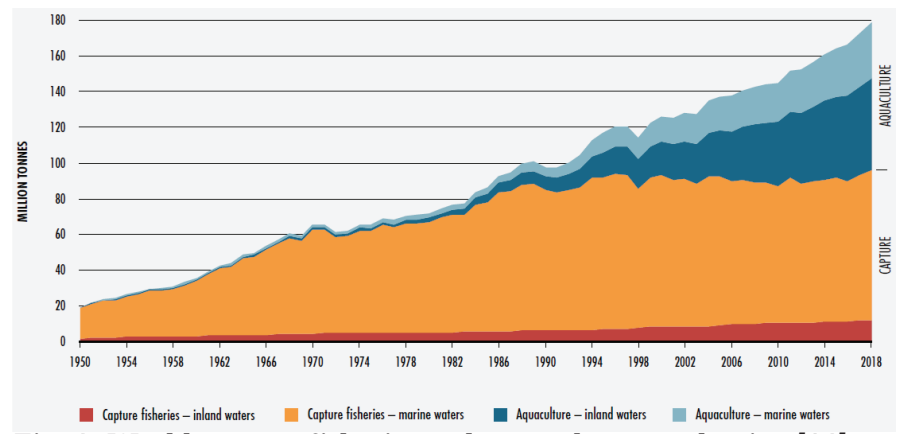

Fig. 4. World capture fisheries and aquaculture production [14]

The World Bank recently undertook an excellent study of aquaculture's present and future role in collaboration with the Food and Agriculture Organization of the United Nations, FAO, and the International Food Policy Research Institute [15]. It estimates that by 2030 , aquaculture will provide close to two-thirds of the global food fish consumption at the same time when catches from wild capture fisheries level off, and demand from an emerging global middle class substantially increases.

The fastest supply growth is likely to come from tilapia, carp, and catfish. Furthermore, fish is playing an increasingly important role in economic development and world trade, So, for example, in 2014, $38 \%$ of all fish produced in the world was exported, and in value terms, over two-thirds of fishery exports by developing countries are directed to developed countries. Fisheries and aquaculture are a vital source of jobs, nutritious food and economic opportunities, especially for small-scale fishing communities. However, threats from large-scale disease outbreaks in aquaculture and climate change-related impacts could dramatically alter this.

Global fish production is estimated to have reached about 180 million tonnes in 2018 (Figure 5),

with a total value in excess of US\$ 400 billion, of which 82 million tonnes (with the aquaculture production valued at about US\$250 billion). Of the overall global consumption in 2018,156 million tonnes were used for human consumption (equivalent to an estimated annual supply of $20.5 \mathrm{~kg}$ per capita), while the remaining 22 million tonnes were destined for non-food uses, mainly to produce fishmeal and fish oil (Figure 5). Total fish production has increased in all continents over the last few decades but has almost doubled during the last 20 years in Africa and Asia [14].

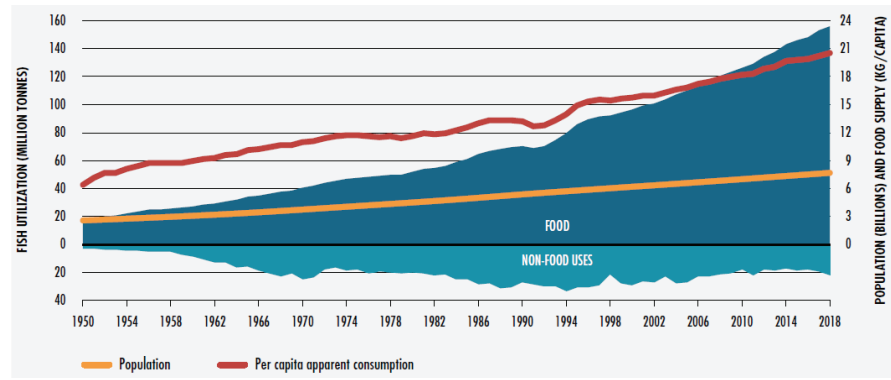

Fig. 5. World Fish utilization and consumption patterns [14].
One of the main reasons behind the growing role that aquaculture plays in meeting the growing demand for food security can be attributed to the rapidly deteriorating environmental conditions and overfished stocks. Based on FAO's assessment, the fraction of fish stocks that are within biologically sustainable levels decreased from $90 \%$ in 1974 down to $66 \%$ in 2017; whereas the percentage of stocks fished at biologically- unsustainable levels increased from $10 \%$ to $34 \%$ percent in the period (Figure 6).

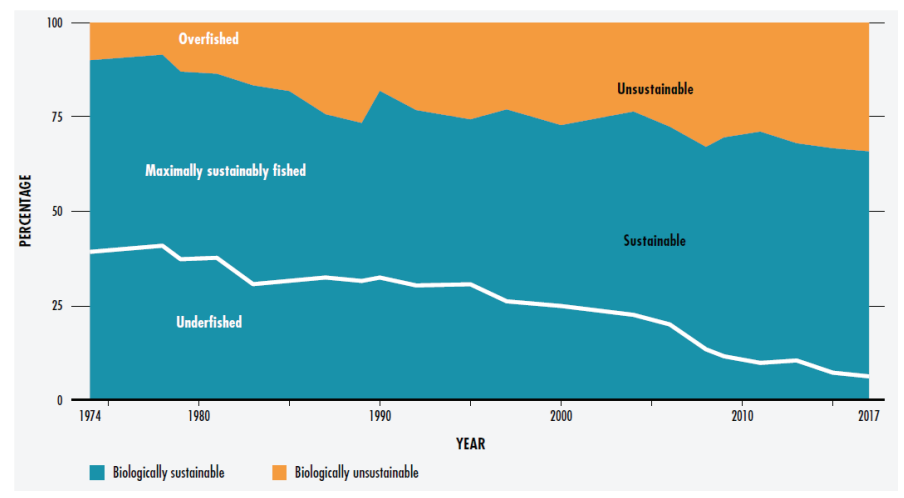

Fig. 6. Global Trends in the State of the World's Marine Fish Stocks, 1974- 2017 [14].

Following a decade-old trend, aquaculture is expected to continue to be the driving force behind the growth in global fish production, with a projected production capacity of 109 million tonnes in 2030 [14]. Consequently, the share of farmed species in global fishery production (for food and non-food uses) is projected to grow from $46 \%$ in 2018 to $53 \%$ in 2030 (Figure 7). However, somewhat slower growth rates are predictedinthedecadesafterwardsduetotheincreased total production capacity, the broader adoption and enforcement of environmental regulations, and the reduced availability of water and suitable production locations. Aquaculture production is also expected to continue the transition from extensive to intensive operations, aiming to better integrate production with the environment by adopting ecologically sound technological innovations.

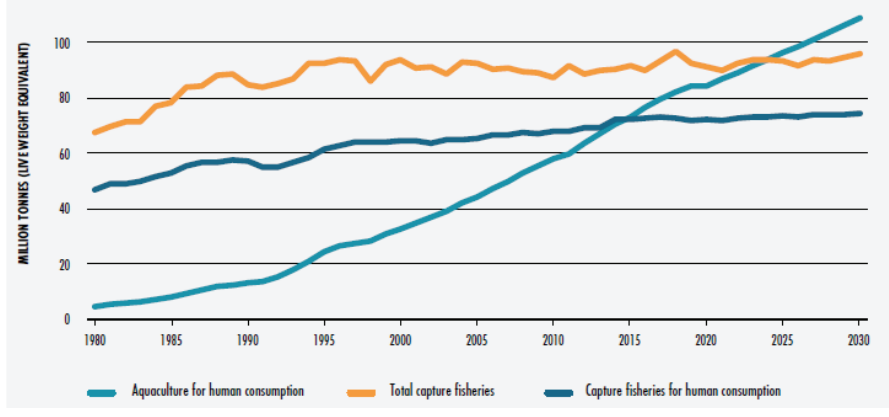

Fig. 7. Global fish production from capture fisheries and aquaculture operations [14].

1. However, the sustainable development and growth of the aquaculture industry is heavily dependent on the availability of inexpensive 
sources of protein since feed accounts for $60-80 \%$ of the operational cost in intensive aquaculture and 40-60 \% in semi-intensive aquaculture systems [4]. Although several protein sources can be used in preparing aquafeeds, fishmeal and fish oil are considered essential for maintaining a rapidly-growing and healthy fish population unless suitable, or better alternatives, can be used. While soy is presently the most common terrestrial plant protein used as fishmeal substitute, many environmental concerns surround the land-use, and fertilizer run-off, requirements associated with soy production. Additionally, palatability and anti-nutritional factors, as well as unintended biological consequences, limit the broad application of unmodified soy and other plant proteins. To mitigate this problem, the industry prioritizes means for improving feed conversion ratios, increasing the recycling of aquaculture fish processing waste, and finding alternative protein sources that can reduce the strong dependence on fishmeal/fish oil [16].

2. The main factors contributing to the growth of the global fishmeal market are increasing demand for naturally derived protein additives in animal feed, expansion of the feed industry, extensive development of salmon aquaculture, and increased consumption of fish as a significant food in various regions of the world. Unfortunately, the over-fishing of the oceans and the severe degradation of the oceanic environment resulted in decreasing fishmeal supply until around 2016 (Figure 8). The recent increase in fishmeal availability can be attributed to increasing world price and enhanced raw material availability obtained from whole fish and fish-residue, a by-product of processing. As shown in Figure 9, a growing share of fishmeal and fish oil will be obtained from fish residue.

3. Aquaculture has long been criticized for "using fish protein to make fish protein". However, implementation of EU regulations (Commission Delegated Regulation No. 1394/2014) is expected to enhance the availability of fishmeal feedstock. This regulation aims to gradually eliminate the practice of discarding undersized fish, under-utilized species, at sea and opens up the possibility for processors to convert this bycatch or marine "rest raw material" into valueadded ingredients due to the high protein and oil content of this by-catch.

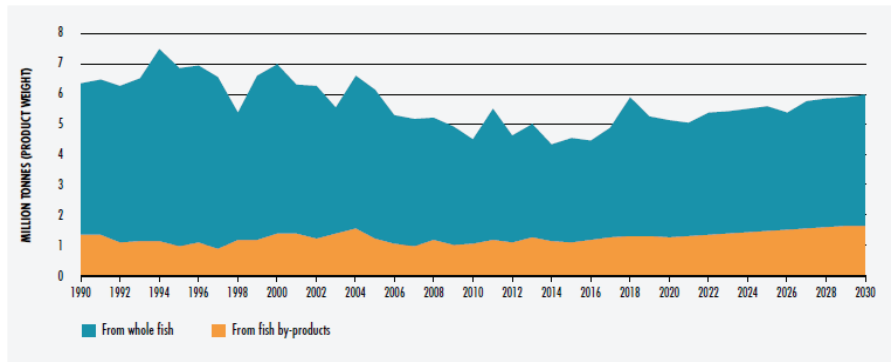

Fig. 8. World fishmeal production, 1990-2030 [14]

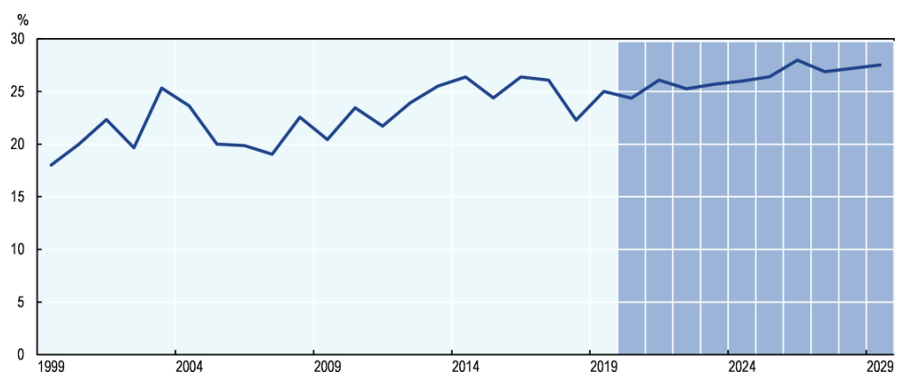

Fig. 9. Share of total fishmeal production produced from the fish residue [17].

The rapid degradation of fishmeal quality and availability resulted in a multi-fold increase in prices (Figure 10), and the fishmeal prices are expected to increase at even a higher rate than that of most fish species (Figure 11). The potential formation of fishmeal shortages (Figure 12), will exasperate that trend unless viable alternatives are identified to meet the world's nutritional demands cost-effectively without damaging the environment $[4,5]$. The emphasis on significantly reducing the footprint of the latter stipulation is driven by the conclusion of many comprehensive environmental impact studies that covered a span of more than 15 years [19-22].

The many life cycle analyses were undertaken that clearly identified that the global environmental performance of aquaculture production is dominated by:

- $\quad$ Aquafeed production is a key driver for climate change, acidification, and cumulative energy use, with the fish-, and livestock-derived ingredients accounting for the highest proportional environmental costs of production. It is also strongly affected by the feed use efficiency.

- Sea-based systems outperform land-based technology in terms of energy demand.

Sea-based systems have a generally higher FCR than land-based ones.

- The fish farm stage of production is a significant contributor to only one of the quantified impacts, namely, eutrophying emissions. Different aquaculture systems and technology components may exert considerably different environmental impacts but, on the average, open systems generate more eutrophying emissions than closed designs.

The environmental impacts of aquaculture 
production are highly variable between regions, indicating substantial scope for environmental performance improvement in the industry as a whole.

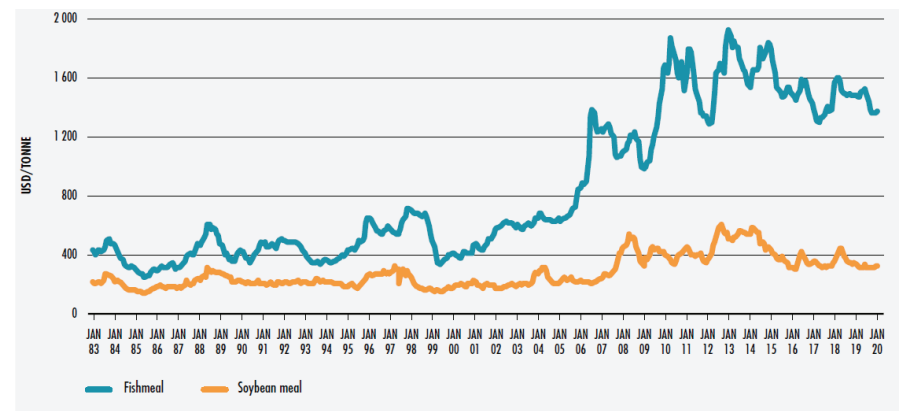

Fig. 10. Fish and Soyameal price trends (prices CIF Rotterdam and Hamburg) [14]

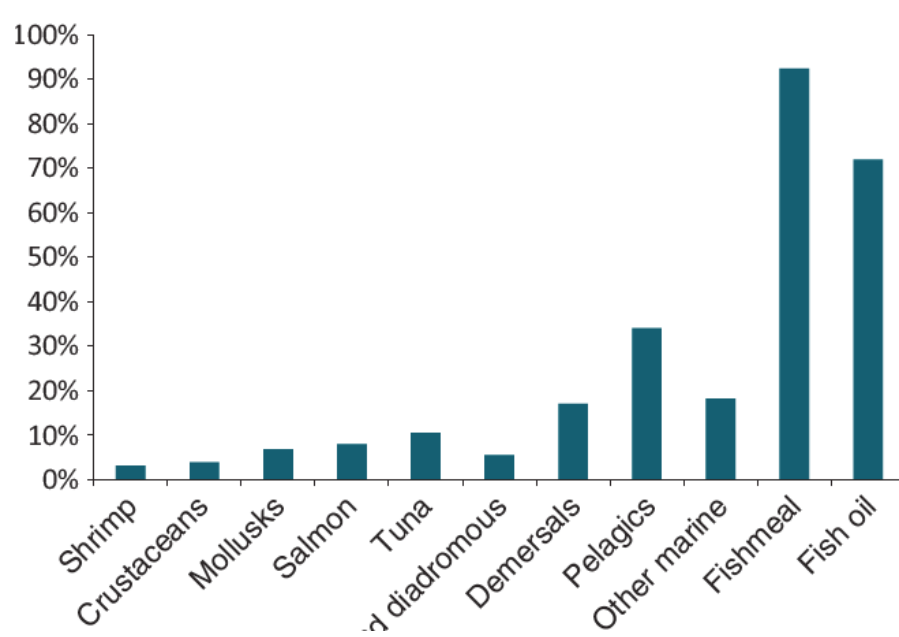

Fig. 11. Projected change in aquaculture commodity prices (between 2010 and 2030) [15].

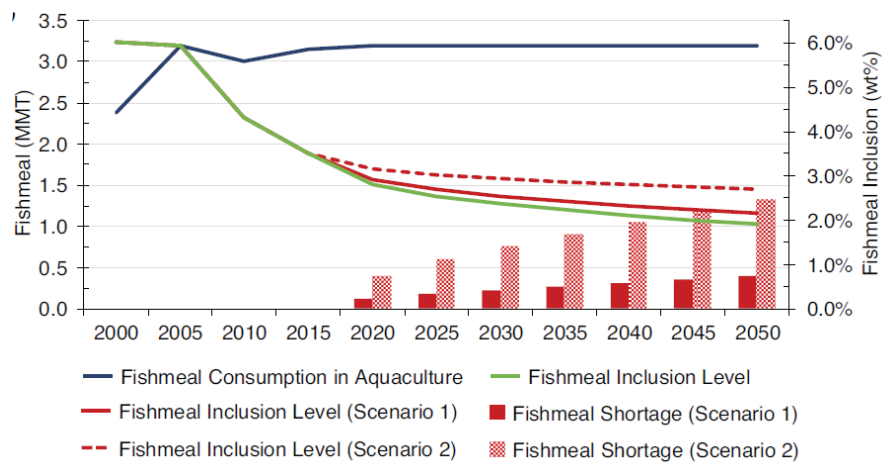

Fig. 12. Projected Fishmeal consumption in aquaculture applications (2015-2050). An average feed conversion ratio, FCR, of 1.2 was used [18]

\section{EFFORTS AIMING AT THE DEVELOPMENT OF ENVIRONMENTALLY- FRIENDLY AQUAFEED}

A significant reduction in the environmental impact associated with meat consumption may be achieved by reducing the amount of wastage in the food supply chain and using more resource-efficient avenues for producing the proteins needed for human and animal growth [6, 9]. The magnitude of the problem can be easily grasped by realizing that in 2018, the global animal feed production is ca 1.1 Billion tonnes worth over \$ 400 billion. To properly address a problem of such magnitude, well-planned collaborative, transnational efforts between private and public sectors are needed if one has to solve such a major problem. Some initiatives have already started, and one hopes that such actions will accelerate if a sustainable solution to the problem of climate change is to be implemented.

For example, to promote this trend and help develop innovative approaches, the European Institute of Innovation and Technology, EIT, supported the establishment of "Climate-KIC International Foundation".

This foundation is Europe's largest public-private innovation partnership whose mission is to catalyze systemic change through innovation in the areas of human activity that have a critical impact on greenhouse gas emissions (cities, land use, materials and finance). It also aims at creating climate-resilient communities.

It, in turn, created "Project-X" the mission of which is "to radically transform the sustainability performance of 10 industry value chains most responsible for biodiversity decline and climate change impacts, over the next ten years. They accomplish this by accelerating access to finance, markets and innovation at the system level and can mobilize up to $\$ 10 \mathrm{~b}$ of additional investment into adopting sustainable innovations globally. They also can help in securing a market commitment from top leaders in the industry.

One of the sub-projects promoted by the aforementioned organization is "Feed-X"; a program the central idea of which is shifting $10 \%$ of the global feed industry (about $107 \mathrm{M}$ tpa) towards more sustainable production of animal feed. This objective is to be accomplished using novel, alternative solutions undertaken by independent entrepreneurs.

The criteria used in selecting such approaches are based on several factors, including:

- reducing harmful environmental effects caused by deforestation, reducing the carbon footprints, and reducing irresponsible fishing practices.

Several large private and public organizations (such as: Skretting, IKEA, World Wildlife Fund, ClimateKIC, and other mission-aligned partners) have already subscribed towards such activities. Armed with the financial and technical support brought in by so many partners, 


\section{CONVERTING HYDROCARBONS INTO SINGLE CELL PROTEIN}

\section{A. A Historical Perspective}

The term single cell protein, SCP, refers to sources of protein extracted from pure or mixed cultures of algae, yeasts, fungi or bacteria, a practice that has been used for millennia by many societies to enhance the nutritional value of certain foods. However, the large-scale use of SCP as a nutritional supplement has its historical roots in Germany, where, during the First World War, about half of all the imported protein was offset by yeast [24, 25]. Some of that tradition is still alive where, for example, single-cell proteins are consumed daily by millions of people and form the basis of popular brands such as "Quorn, Marmite and Vegemite".

Unfortunately, the carbohydrates that have been traditionally used as a substrate for such operations are presently not easily available and/or costeffective. On the other hand, spent yeast cells from ethanol fermentation processes are commonly blended with dried distiller's grains, and "solubles" in terrestrial animal feeds. However, the high fiber content of this blend limits its use in aquaculture [26]. Similarly, algae are grown commercially in ponds or bioreactors for use in food, cosmetics, oil and nutritional supplements. However, the large-scale application of algae as an alternative protein source is presently limited by technical challenges and high production costs. Consequently, significant efforts were dedicated over the past several decades aiming towards the use of hydrocarbon-based substrates for the production of SCP.

The growing interest in using biotechnology to address the need for meeting human protein consumption resulted in an explosive growth in $R \& D$, patenting and commercialization. These are reviewed by Ritala et al. [27], who provided excellent insight into the technical and commercialization factors. The authors also noted that industries and universities in China have been very active in filing patents related to SCP in recent years, particularly those related to SCP production by fermenting agricultural or food residues with bacteria, yeast and mixed populations. Consequently, more than half of the patents awarded since 2001 having been filed in China.

The attempt to develop large-scale operations for the production of SCP began in earnest in the 1960s when British Petroleum became interested in the growth of microorganisms in the wax fraction, which has to be removed from gas oils. A 16,000 tpa plant was built with the product being marketed as a replacement for fish meal in high-protein feeds and as a replacement for skimmed milk powder in milk substitutes [23]. The Soviets were particularly enthusiastic about this approach and established several large "proteinvitamin concentrate plants" next to several refineries. However, the problems associated with the complete removal of heavy hydrocarbons from the bacterial biomass, combined with the rapid increase in the value of all liquid petroleum fractions, resulted in the adoption of other less expensive hydrocarbon-based substrates such as methanol.

For example, ICI commissioned a 60,000 tpa plant based on the use of methanol as a substrate, in which a bacterium (Methylophilus methylotrophus) was grown using what is still considered to be the world's largest airlift fermenters (1,500 m3 each). The product was marketed as a feed constituent providing a source of energy, vitamins and minerals, as well as a highly balanced protein source.

Following ICI success, Shell Research Center in Sittingbourne developed a continuous process for directly converting methane into SCP. This approach avoids the toxicity problems associated with the use of alkanes and has significant economic advantages over other hydrocarbon-based SCP routes. The economic advantages of using methane as compared to other substrates are quite significant. It is a relatively inexpensive substrate that is available in a highly pure state worldwide, and its use allows for achieving higher reaction rates, better selectivity, and greater conversion efficiencies, factors that are critical for the sustainability of this approach. Shell's technical achievements are summarized by Hamer [28].

The company planned for the establishment of a 100,000 tpa plant in Amsterdam. However, all commercialization activities by both ICI and Shell were stopped because of the turmoil that plagued oil and gas prices at that time, and by concerns about the ability to compete with abundant supplies of relatively low-priced soymeal and fishmeal. It is, however, interesting to note that the airlift reactors built by ICI were used by "Marlow Foods UK" to produce one of the most successful SCP products exclusively used for human consumption as a meat substitute "Quorn ${ }^{\mathrm{TM}}$ " [29].

At present, three major organizations/consortia have a commercial interest in converting natural gas into SCP. Unibio A/S leads the first group, the second by Calysta Inc., whereas VTT Ltd. is investigating various options for coupling farm methane generation with the production of microbial oil and feed protein [30]. An India-based startup, "StringBio" recently got involved in the field [31].

In the mid-1980's, Dansk BioProtein A/S was established to commercialize the conversion of Methane into SCP using the naturally occurring Methane-consuming microorganism (Methylococcus 
capsulatus) discovered by Dr. M. Naguib from the Max Planck Institute. In collaboration with the Danish Technical University, DTU, the company improved the design of their fermentor, cumulating with the award of the patents protecting the use of the U-Loop bioreactor. The company then collaborated with a Norwegian consortium that included Statoil, but that relationship did not survive long because of disagreement of future R\&D plans [32].

Efforts aiming at developing the technology continued in Denmark, where Unibio A/S was founded in 2001. It collaborated extensively with the DTU, and in 2010, a $7.5 \mathrm{~m} 3$ pilot facility was built at the University of Trinidad and Tobago. In 2016, Unibio A/S inaugurated an 80 tpa pilot facility built in Kalundborg (one of the world's leading centers for demonstrating the circular economy concept and the advantages of process integration $[33,34])$.

Samples from that plant were used for additional feed tests that revealed that its trademarked product, Uniprotein ${ }^{\circledR}$, can be used as a partial replacement of prime fishmeal without adverse effects and has gained approval from the European Union for inclusion in feed prepared for all animal and fish species. Furthermore, its use may enable for eliminating the need for incorporating medical zinc oxide in piglet feed, a practice that may be in the process of being banned in Europe. In partnership with the Russian firm Protelux, the first full-scale production plant (6,250 tpa) was completed in 2020, in which four 35 $\mathrm{m}$ high U-Loop fermenters are used (Figure 13). The protein-rich product is intended as an ingredient to produce feed for the pig and feed markets. The low cost of natural gas and electricity is expected to create competitive advantages for Russia when it comes to the production of bio protein [35].

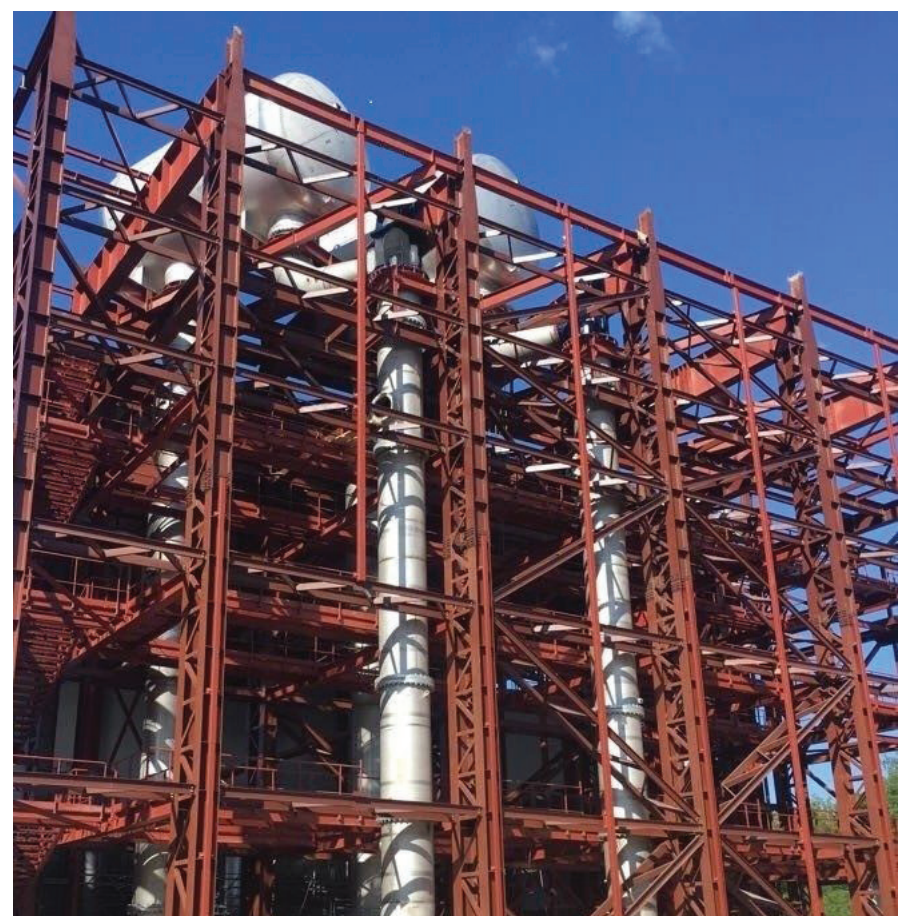

Fig. 13. Unibio/P plant in Russia [35].
The other group that is very active in this field owes its existence to the period near the end of the 20th century, where interest in converting methane into SCP was re-stimulated by the availability of abundant supplies of North Sea natural gas, the steady increase in the price of fishmeal, and the presence of large local Salmon aquaculture operations. Following the failure of the joint venture with "Dansk BioProtein A/S", Norferm AS was developed as a joint venture between Statoil and DuPont. This consortium designed and built a 10,000 tpa plant at Tjeldbergodden, Norway that started operating in 1999 [36]. Their product trademarked as "BioProtein" was widely marketed and approved for use as a safe constituent in animal feed formulations and limited human consumption [37].

However, the plant was shut down in 2006, presumably due to the high NG prices charged at that particular time and location. The IP was consequently transferred to "BioProtein" (a consortium of three Norwegian academic institutions), which continued to do work validating the positive health effects of microbial protein in salmon, pigs and other livestock [32].

A decade later, Calysta (a company founded in Menlo Park, California in 2011) acquired the technology from BioProtein A/S in 2014, thereby merging their expertise in fermentation biology with a proventrack commercial-scale fermenter design and an EUapproved microbial protein. In collaboration with the Centre for Process Innovation and Otto Simon Ltd, a 100 tpa technology development and market introduction facility was designed and built-in Teesside, UK [38]. Their product is marketed as "FeedKind ${ }^{\circledR}$ " protein. Efforts are presently underway to obtain approval in the US for farm animals, pets, and ultimately human consumption.

Calysta announced a joint project with the multinational feed giant Cargill to establish a largescale production facility in half of Cargill's site in Memphis, TN. This facility is to occupy 37 acres to

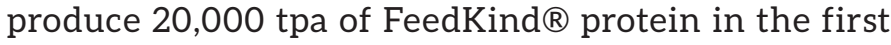
phase, with an additional 180,000 at a later stage [39]. This plant will be home to the world's largest gas fermentation operation to produce Calysta's FeedKind $\AA$ protein. In 2019, the venture arm of BP (the British oil and gas giant) announced its $30 \$$ Million investment in the partnership, with BP supplying power and gas to Calysta feed protein plants [40]. However, although the sod-turning event took place in April 2017, there is no publicly available news concerning the progress achieved in this project.

Recently, Calysta formed a joint venture with Adisseo in Paris (a world leader in feed additives for animal nutrition) and the Bluestar Group in Beijing to construct a FeedKind production facility in China. The last organization is one of China's largest 
chemical organizations that focuses on new chemical materials and animal nutrition and is connected with the US's Blackstone Group as a strategic investor. The production facility is located in the Changshou National Economic and Technological Development Zone (Chongqing City) and will initially produce 20,000 tpa of FeedKind protein, exclusively for Asian markets, with a second phase bringing in an additional capacity of 80,000 tpa. Construction of that facility started in the first week of 2021 and is projected to come online in 2022 [41]. Considering that China is the world's largest fishmeal importer, the construction of such a facility represents a big step towards improving the security of supply for highprotein content ingredients wildly used in preparing compounded feed formulations.

\section{TECHNICAL CHALLENGES FACING THE PRODUCTION OF SCP}

\section{A. Introduction}

Although many microorganisms can be used to convert natural gas into high-protein biomass, attention is focused on Methylococus capsulatus (Bath) because its suitability for large-scale operations has already been proven, and an extensive database for its suitability as an ingredient in animal feed and human consumption already exists. It is a naturally occurring microorganism responsible for much of the methane naturally emitted by the soil being converted into nutritious compounds that are consumed by lowerlevel organisms. The overall reactions involved can be represented by [42]

$\mathrm{CH}_{4}+0.104 \mathrm{NH}_{3}+1.45 \mathrm{O}_{2} \rightarrow 0.52 \mathrm{CH}_{1.8} \mathrm{O}_{0.5} \mathrm{~N}_{0.2}+0.48 \mathrm{CO}_{2}+1.69 \mathrm{H}_{2} \mathrm{O}$
The spray-dried form of the bacteria is a light brownish, free-flowing granulate that resembles powdered milk but, as shown in Figure 14, has a substantially higher protein and fat contents with high amounts of phosphorus, potassium and magnesium. Furthermore, as shown in Table I, the amino acid profile of the protein obtained from that bacteria closely matches that of high-quality fishmeal and is thus well suited as direct feed for animals, particularly those with a short life span (e.g. shrimp, poultry, calves, ducks, fish, dogs, and cats).

The product produced by both companies performed well in the extensive sets of feeding tests undertaken by the companies and independent agencies. They confirmed that not only can it be used as a replacement for fishmeal, but its ability to stimulate the immune system, combined with the high digestibility of the nitrogen present in the protein, resulted in achieving enhanced growth rates, improved animal survival rates, better nitrogen retention, and reduced susceptibility to digestive tract inflammation [42-45]. Most importantly, significant improvement in the feed conversion ratio was observed as the fishmeal was replaced with the alternate bio protein, a factor that is critically relevant to the operational profitability [44]. It may therefore be considered as a "super-prime" fishmeal.

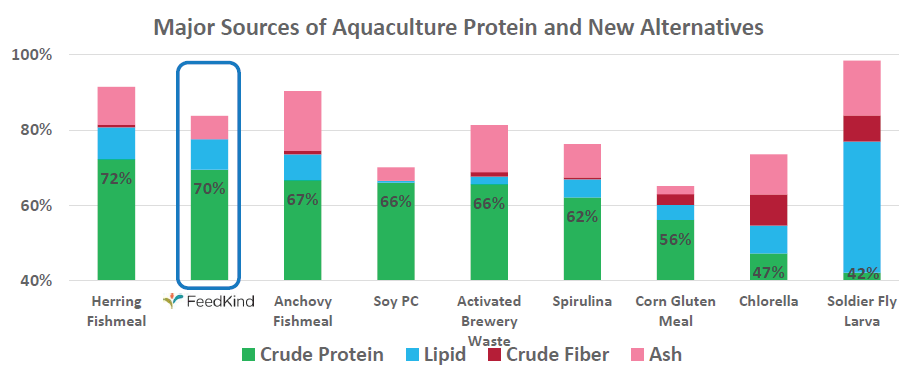

Fig. 14. Major sources of protein-containing feed ingredients [42]

Table I

PROFILE OF SELECTED ESSENTIAL AMINO ACIDS PRESENT IN PROTEIN SOURCES [46].

\begin{tabular}{|c|c|c|c|c|}
\hline & Skim milk powder & Fish meal & Soya bean meal & BioProtein \\
\hline Crude protein & $36,1 \%$ & $63,8 \%$ & $45,8 \%$ & $70,0 \%$ \\
\hline \multicolumn{5}{|c|}{ Amino acids $(\mathrm{g} / \mathrm{kg})$ : } \\
\hline Methionine & 8,4 & 16,1 & 5,6 & 18,7 \\
\hline Cystein & 2,7 & 5,6 & 6,1 & 4,2 \\
\hline Lysine & 26,0 & 44,0 & 24,6 & 43,0 \\
\hline Threonine & 14,8 & 24,3 & 15,7 & 31,0 \\
\hline Tryptophan & 4,7 & 6,6 & 5,5 & 14,8 \\
\hline Arginine & 11,3 & 33,8 & 29,2 & 41,3 \\
\hline Total & 69,9 & 130,4 & 86,7 & 153,0 \\
\hline
\end{tabular}




\section{B. Production Methodology}

The aforementioned natural gas fermentation approach used by the two leading technology providers in this field (Unibio A/S and Calysta) is relatively simple and relies on the use of processing steps that are commonly encountered in many food-processing operations (Figure 15). The two organizations use almost identical main microorganisms (Methylococus Capsulatus) and the same bioreactor type (continuous, forced circulation, loop bioreactor).

The major difference between both companies lies, therefore, in the design and configuration of their respective patented bioreactors $[47,48]$. Unfortunately, only a few independent laboratory-scale experimental investigations were conducted to assess the effect of various design and operating conditions on the reactor performance of [49]. However, in order to enhance the bioreactor productivity, all the experimental and simulation findings point out to the need for enhancing the rate of interphase mass transfer, which is usually quantified by the kLa value. This is driven by the very low water solubility of the gases involved in this process $\mathrm{CH} 4, \mathrm{O} 2$.

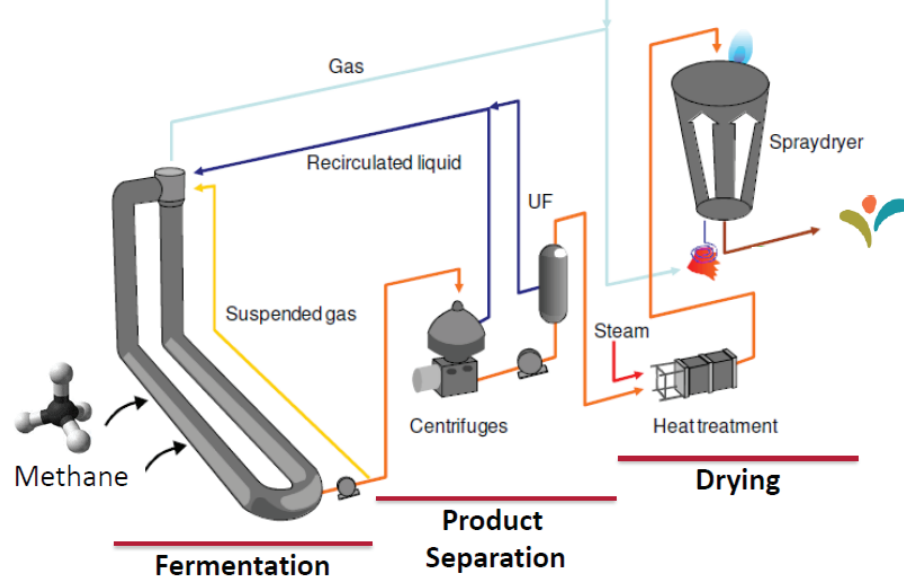

Fig. 15. Typical flow diagram for the bioconversion of natural gas into animal feed [42].

The bioprocess engineering approach used by both companies mimics what happens in nature but attempts to create an environment that maximizes the rate by which the microorganisms grow and the efficiency by which they utilize the substrate "Methane". This, in turn, is affected by many parameters such as: type and concentration of microorganism used, broth composition, liquid phase concentration of methane/ oxygen/CO2, operating temperature and pressure, $\mathrm{pH}$, micronutrients, and mixing patterns in the bioreactor. In order to reduce the overall capital costs and avoid the complexities associated with the recycling of unutilized reactants, the bioreactor is operated in a fashion in which the gas phase passes only once through the reactor. In contrast, the liquid broth is recycled through the fermentor/separator using a pump. Consequently, it is necessary to achieve very high conversion efficiencies of the gaseous reactants (CH4 and O2) in order to lower the operating costs [50]. Three reactor types that can meet this requirement have been successfully used for converting natural gas into bioprotein at the lab scale [49].

All of these can be considered variants of the simple multiphase recirculating loop reactor system but differ in the method used for inducing fluid movement (e.g. pumps, in-line axial flow mixers, or airlift) and in the orientation of the tubular section (vertical vs. horizontal). In all cases, it is necessary to maintain:

- high interphase mass transfer rates,

- removing the heat generated by the exothermic biochemical reaction, and

- $\quad$ reducing the concentration of inert gases and $\mathrm{CO} 2$ in the recycle stream.

A significant part of the unit is also operated at somewhat elevated pressures $(2-5 \mathrm{~atm})$ in order to overcome the limitations caused by the low solubility of the reactant gases. Optimally designed reactor systems are therefore essential for achieving a sustainable biochemical operation. A simple analysis of the forced-loop bioreactor performance (that considers the impact of $\mathrm{CO} 2$ generation on interphase mass transfer) clearly identifies that the system's overall performance is mass transfer limited [51, 52]. It also suggests that reactor productivities as high as $12 \mathrm{~kg} / \mathrm{h} \mathrm{m} 3$ can be achieved provided that a relatively high mass transfer coefficient can be achieved without detrimentally affecting the microorganisms (Figure 16).

This productivity is almost 3 -fold what previous systems achieved and suggests that substantial reductions in capital and operating costs can be achieved under optimal design and operating conditions.

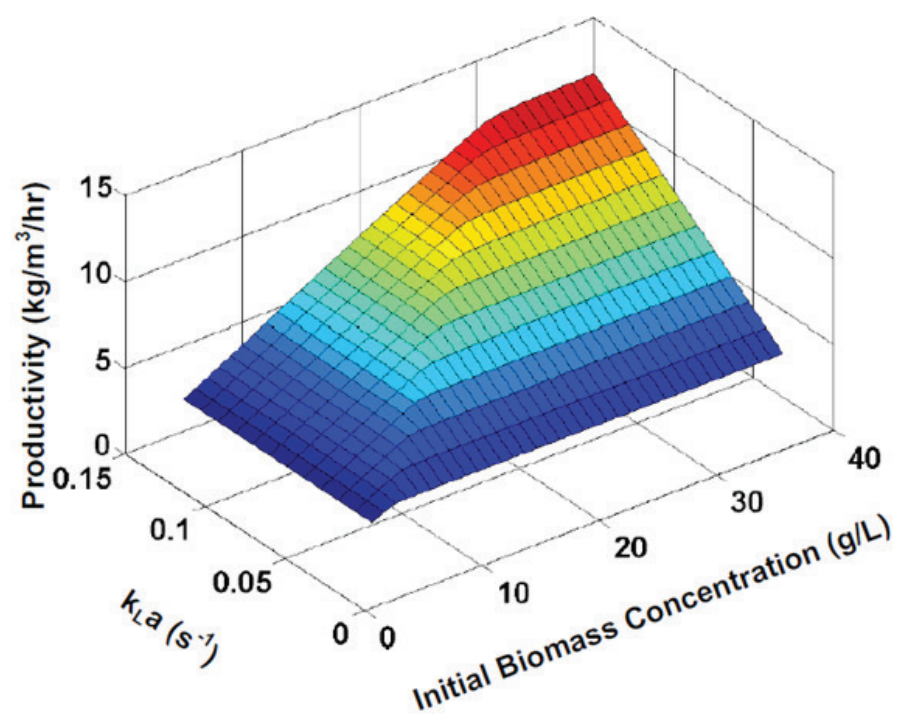

Fig. 16. Effect of operating conditions on the average bioreactor productivity ( $5 \mathrm{~atm}, 45^{\circ} \mathrm{C}$, recycled $\mathrm{CO} 2$ is $10 \%$ of equilibrium value) [52]. 
In this regard, it is interesting to note that the recent results (obtained using the slowly-coalescent system of $0.05 \mathrm{M} \mathrm{KCl}$ ) indicates that very high volumetric mass transfer coefficients can be achieved by incorporating static mixers in the vertical legs of the U-Loop bioreactor used by Unibio A/S in their process [53]. These results are several times larger than the upper range shown in Figure 16, suggesting that there may be room for further enhancement provided that the microorganisms are not adversely affected by the high shear rates encountered [51].

VII. ECONOMIC AND ENVIRONMENTAL CHALLENGES FACING THIS APPROACH

\section{A. Introduction}

The proposed approach to producing high-protein biomass offers several environmental advantages when compared to the intensive livestock approach, where about a quarter of the Earth's land area is dedicated to grazing (mostly for cattle, sheep and goats), and a third of all arable land is used to grow feed crops for livestock. The bioprotein produced is a non-polluting non-GMO microorganism (free from toxins, dioxin and heavy metals due to the controlled production process and the use of food-grade trace minerals), the production of which poses very low water demands and land-use requirements.

The history of previous industrial attempts to convert natural gas into a protein-rich animal feed component clearly shows a strong vulnerability to fluctuations in the price of the main input constitutes (natural gas and energy, Figure 17), as well as the prices of alternate feed formulation constituents, such as Soymeal. A preliminary techno-economic study, in which a sensitivity analysis to various factors affecting economic viability was undertaken, confirmed this vulnerability to market forces [54].

It also indicated that the economic sustainability of this approach is mostly influenced by the price commanded by the products, and to a lesser extent, by the cost of the feedstock used. These observations are mostly driven by the relatively large capital costs involved in such operations (the second most important parameter affecting economic sustainability).

These findings emphasize the need to explore various means by which the capital cost can be lowered (e.g. process intensification and process integration). However, the price of long-term wellhead methane can be significantly lower, particularly when SCP production is considered as an alternative to flaring (an operation that is often used to control methane discharge from refineries, fracking operations, coal beds, and bio-digestors). Such economic observations accentuate the need to improve SCP production's environmental performance to benefit from the forthcoming financial incentives used to combat

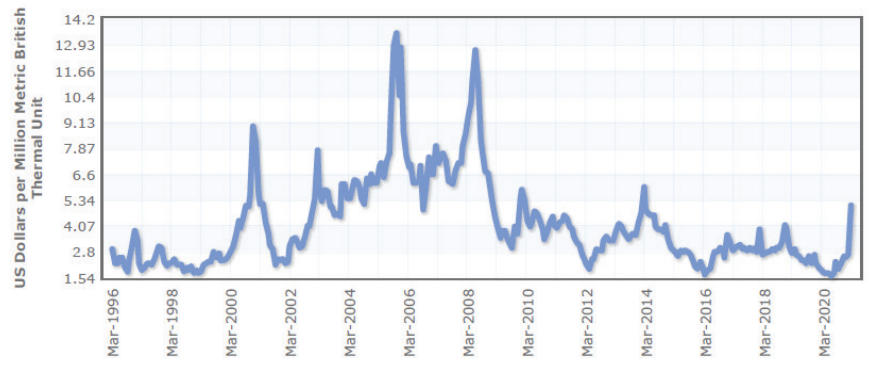

climate change.

Fig. 17. Strong fluctuations in the price of delivered Natural Gas [5].

\section{B. Environmental Benefits}

The high-protein-content animal-feed ingredient produced by both technologies can be considered as: nutritious, affordable, safe, pesticide-free, traceable that can be used as a non-GMO, uses no arable land and almost no water in its production. Its production is also immune to seasonality or other undue climate influences (e.g., extreme temperatures, droughts, and floods). In some feed tests, certain unique nutritional characteristics, and extra health benefits, were observed. These factors could create some additional value for the animal feed formulators.

For example, the planned production rate for the Chongqing City plant (100,000 tpa) is estimated to [41]:

- $\quad$ Replace the fishmeal made by wild-catching 420-450 k tonnes of fish,

- $\quad$ Free up as much as $535 \mathrm{~km} 2$ of land used for producing soymeal, and

- $\quad$ Save nine million cubic meters of water.

However, with the present global concern about climate change, it is very possible that both positive and negative financial incentives may be imposed on businesses in order to accelerate the adoption of novel technologies and management approaches that can result in reducing GHG emissions. Depending on the overall environmental performance of the feed production approach, such incentives can significantly affect the financial sustainability of the production methodology. To address the additional uncertainty caused by this socio-political factor, it is necessary to have reliable estimates concerning the environmental impact of producing SCP that considers a wide range of technical/economic/ policy scenarios.

A good example of such an effort is the study conducted by the "Carbon Trust" (an organization that advises governments and companies on emission reduction), where several options for reducing the environmental effects of the food system were analyzed. Their report is based on industrial performance values and 
compared how much land is needed, how much water is used, and how much $\mathrm{CO} 2$ is emitted by the various feed production methods [55]. It found that when fossil-based methane is used for power generation and as a feedstock, the carbon footprint per tonne of feed produced is much higher than that associated with many other sources of protein. On the other hand, this can be reduced to less than half the original emission levels if biogas methane is used for feedstock and energy. This advantage is further enhanced by the fact that SCP production utilizes significantly less water than plant-based protein sources and does not take up any farmland [55]. The latter is very critical to the issue of rapid biodiversity decline.

This vulnerability is most probably one of the biggest reasons behind the observation that two major consortia presently involved in the industrial-scale fermentation of natural gas contain partners that cover the whole range of expertise needed to succeed in this emerging field (NG supply; Fermentation technology; process engineering, and animal feed marketing and utilization). For example, the consortium led by Calysta includes world leaders such as: BP Adisseo, Temasek, AquaSpark, Mitsui and Cargill; whereas that led by Unibio includes: Mitsubishi Corp. and Cermaq, where the latter is one of the world's largest salmon farming companies. By spreading the risks amongst all members of the end-to-end value-chain-wide consortia, it may be possible to improve the longterm food security and sustainability for the world's growing population.

However, the sustainability of this approach can still benefit from addressing the following issues:

- Promoting the use of bio-protein as an ingredient in formulated feed for farmed fish, crustaceans, poultry, livestock and pets, where the incorporation of bio-protein is known to result in measurable advantages to their growth/ health. Thanks to the efforts by several agencies, it appears that the European Union has approved for including dried Methylococcus capsulatus (Bath) bacterium in the feed formulations for most animal and fish species [37; 56]. This may also result in commanding higher market value based on the superior performance achieved by SCP-containing formulations and/or their beneficial environmental impact.

- $\quad$ Most of the food safety and feeding tests were conducted using cold climate species. Therefore, it is advisable to develop a similar database for feeding animals prevailing in temperate/ subtropical/tropical climes, where the market growth is projected to be higher.

- $\quad$ Significant improvement in the performance of fermentation systems can also be achieved by using process-intensification approaches [57-60]. In the present situation, this is mainly achieved by enhancing the rate of interphase mass transfer in the bioreactor. This, in turn, enhances the rate of bioconversion and conversion efficiency while reducing reactant losses. However, growing concern was recently expressed about the need to carefully examine the fundamental relation between capital expenditures (CAPEX) and operational expenditures (OPEX) of intensified and nonintensified bio-based processes. In the current environment, where the emphasis is placed on reducing the environmental footprint of chemical and biochemical operations, there is a growing indication that greater importance should be given to OPEX minimization as a means for sustainable bio-economic development [61].

- Similarly, "Process Integration" is known to reduce the operating costs mainly by applying the concept of waste minimization to various process and energy streams [62 - 64]. In the case at hand, the potential use of methane-rich waste streams (such as those encountered in refinery flares, coal bed methane, fracking flares, biodigesters, etc.) would be natural candidates. Such an approach would be an excellent example of a win-win situation while racing to reduce carbon emissions across many fronts. Unfortunately, the typical scale of biodigestion operations is relatively small [65], rendering difficult the sustainability of such an approach.

\section{THE WAY FORWARD}

There is a growing worldwide concern regarding the approach being used to meet the present demand for protein, a nutrient that is essential for human health. This concern is exasperated by the large growth in demand projected for the next few decades and the growing awareness of the detrimental environmental impacts it has on land and water resources as well as the associated GHG emissions.

Springmann et al. [66] have recently analyzed several options for reducing the environmental effects of the food system, including:

- $\quad$ dietary changes geared towards using healthier and more environmentally-friendly diets,

- improvements in the technologies and management practices used, and reducing food loss and waste.

They found that no single measure is sufficiently capable of keeping these effects within all planetary boundaries. However, a synergistic combination of all possible measures will be is needed to sufficiently mitigate the projected increase in environmental 
pressures.

The approach proposed in this paper discusses the potential for adopting an alternative way for meeting the present and future demands in a sustainable fashion. It also presents means by which the economic and environmental uncertainties can be addressed, particularly when the gases, otherwise flared during oil and gas production and processing, can be used as a feedstock and/or source of energy. However, a significant R\&D effort is needed before this approach is widely accepted.

\section{ABBREVIATIONS}

FAO Food and Agriculture Organization of the United Nations

FCR Feed conversion ratio

NESRC Natural Sciences and Engineering Research Council of Canada

tpa Tonnes per annum

UNEP United Nations Environmental Program

UTT University of Trinidad and Tobago

WB World Bank.

\section{ACKNOWLEDGEMENT}

The authors acknowledge the financial support provided by NSERC and Alpha Tau Ltd.

\section{REFERENCES}

[1] FAO, The State of World Fisheries and Aquaculture. Rome, Italy: Office of Knowledge Exchange FAO, 2010.

[2] UNEP Global Environmental Alert Service, "Growing greenhouse gas emissions due to meat production," www.unep.org/geas ,2012

[3] Pew Commission on Industrial Farm Animal Production, Putting Meat on the Table: Industrial Farm Animal Production in America. Baltimore: Pew Commission on Industrial Farm Animal Production, http://www.ncifap.org ,2008

[4] E. Röös, C. Sundberg, P. Tidåker, I. Strid, and P.A. Hansson, "Can carbon footprint serve as an indicator of the environmental impact of meat production," Ecol. Ind., vol. 24, pp. 573-581, 2013.

[5] P.J. Gerber, H. Steinfeld, B. Henderson, A. Mottet, C. Opio, J. Dijkman, A. Falcucci, and G. Tempio, Tackling Climate Change Through Livestock - A Global Assessment of Emissions and Mitigation Opportunities. Rome: Food and Agriculture Organization of the United Nations, 2013.

[6] S. Smetana, A. Mathys, A. Knoch, and V. Heinz, "Meat alternatives: Life cycle assessment of most known meat substitutes." Int. J. Life Cycle Assess., vol. 20, pp. 1254-1267, 2015.

[7] H.C.J. Godfray et al., "Meat consumption, health, and the environment," Science, vol. 361, Issue 6399, eaam5324, 2018
[8] P.F.S.Filho et al., "Mycoprotein: Environmental impact and health aspects," World J. Microbiol. Biotech., vol. 35, p. 147, 2019.

[9] U. Sonesson, J. Davis, A. Flysjö, J. Gustavsson, and C. Witthöft, "Protein quality as functional unit- a methodological framework for inclusion in life cycle assessment of food," J. Clean Prod., vol. 140, pp. 470-478, 2019.

[10] J.L. Johnston, J.C. Fanzo, and B. Cogill, "Understanding sustainable diets: A descriptive analysis of the determinants and processes that influence diets and their impact on health," Food Security, Environ. Sustain. Adv. Nutr., vol. 5, pp. 418-429, 2014.

[11] FAO, Climate-smart Agriculture: Policies, Practices and Financing for Food Security, Adaptation and Mitigation. Rome: Food and Agriculture Organization, 2010.

[12] J.J. Hyland, M. Henchion, M. McCarthy, and S.N. McCarthy, "The role of meat in strategies to achieve a sustainable diet lower in greenhouse gas emissions: A review," Meat Science, vol. 132, pp. 189-195, 2017.

[13] FAO, Mapping Supply and Demand for AnimalSource Foods to 2030, Animal Production and Health Working Paper; Rome, Italy: FAO, 2011.

[14] FAO, The State of World Fisheries and Aquaculture 2020. Sustainability in action. Rome: FAO, https://doi.org/10.4060/ca9229en, 2020

[15] World Bank, FISH To 2030. Prospects for Fisheries and Aquaculture. WORLD BANK Report \# 83177-GLB, 2014.

[16] R.L. Naylor, R.W. Hardy, D.P. Bureau, A. Chiu, M. Elliott, A.P. Farrell, I. Forster, D.M. Gatlin, R.J. Goldburg, and K. Hua, "Feeding aquaculture in an era of finite resources," 2009.

[17] https://www.oecd-ilibrary.org/sites/4dd9b3d0e n / index.h t m l ? it e m Id =/ content/ component/4dd9b3d0-en\#figure-d1e19895 ,2021

[18] S.W. Jones, A. Karpol, S. Friedman, B. T. Maru, and B.P. Tracy, "Recent advances in single cell protein use as a feed ingredient in aquaculture," Current Opinion in Biotech., vol. 61, pp. 189-197, 2020.

[19] F.A. Bohnes, H. M. Zwicky, S. Jørgen, and L. Alexis, "Life cycle assessments of aquaculture systems: A critical review of reported findings with recommendations for policy and system development," Reviews in Aquaculture, vol. 11, pp. 1061-1079, 2019.

[20] G.Philis , F. Ziegler, L. C. Gansel, M. D. Jansen, E. O. Gracey, and A. Stene, "Comparing life cycle assessment (LCA) of Salmonid aquaculture production systems: Status and perspectives," Sustainability, vol. 11, p. 2517, doi:10.3390/ su11092517,2019

[21] Bohnes, F.A., and Laurent, A., "LCA of 
aquaculture systems: methodological issues and potential improvements". Intern. J. Life Cycle Assessment, 1-14, DOI: 10.1007/s11367-0181517-x 2018

[22] N.Pelletier, P. Tyedmers, U. Sonesson, A. Scholz, F. Ziegler, A. Flysjo, S. Kruse, B. Cancino, and H. Silverman, "Not all Salmon are created equal: Life cycle assessment (LCA) of global Salmon farming systems," Environ. Science \& Techn., vol. 43, pp. 8730-8736, DOI: 10.1021/es9010114, 2009

[23] https://projectxglobal.com/our-pilots/feed-xchallenge,2021

[24] C. Israelidis, Nutrition - SCP, 1986, http://www. biopolitics.gr/HTML/PUBS/VOL1/isreali.htm ,2021

[25] G. Suman, M. Nupur, S. Anuradha, and B. Pradeep, "Single cell protein production: A review," Int. J. Curr. Microbiol. Appl. Sci., vol. 4, pp. 251-262, 2015.

[26] D.M. Gatlin et al., "Expanding the utilization of sustainable plant products in aquafeeds: A review," Aquacukture Research, vol. 38, pp. 551579, 2007.

[27] A. Ritala, S.T. Häkkinen, M. Toivari, M. G. Wiebe, "Single cell protein-State-of-the-art, industrial landscape and patents 2001-2016," Front. Microbiol., 2017, https://doi.org/10.3389/ fmicb.2017.02009,2021

[28] G. Hamer, "Methane: Commercial substrate or commercial product, enzyme and microbial" Techn., vol. 9, pp. 503-505, 1987.

[29] J. A. Whittaker, R. I. Johnson, T. J. A. Finnigan, S. V. Avery, and P. S. Dyer, "The biotechnology of quorn mycoprotein- Past, present and future challenges"; in Grand Challenges in Biology and Biotechnology, in Grand Challenges in Biology and Biotechnology, H. Nevalainen Edit., pp 5979 Springer Nature Switzerland AG., 2020,

[30] http://www.vttresearch.com/media/news/ protein-feed-and-bioplastic-from-farm-biogas [2016]

[31] https://m.economictimes.com/small-biz/ startups/features/transforming-methane-gasto-meat-equivalent-string-bio-is-making-itpossible/articleshow/73079312.cms April 2021

[32] Daihassan, TheHistory of SCPProduction,https:// daihassan.tripod.com/id56.html ,2021

[33] Unibio, Pilot Plant, 2017, http://www. unibio. $\mathrm{dk} /$ technology/pilot-plant, 2021

[34] A. Urbinati, D. Chiaroni, V. Chiesa, "Towards a new taxonomy of circular economy business models," J. of Cleaner Production, vol. 168, pp. 487-498, 2017.

[35] "World's first commercial-scale plant of this type uses novel U-loop technology," https://www. feedstrategy.com/animal-feed-manufacturing/ unibio-protelux-complete-methane-to-proteinplant/, 2021
[36] "Norferm expands into fermentation optimization," https://www.icis.com/explore/ resources/news/2004/06/18/590388/norfermexpands-into-fermentation-optimization/ , 2021

[37] NSCFS- Norwegian Scientific Committee for Food Safety, "Opinion on the safety of BioProtein by the scientific panel on animal feed of the Norwegian scientific committee for food safety," publication data, 2006.

[38] J. Byrne, "New dawn for gas to feed protein as Calysta flags up 2017 production start date," 2015, https://www.feednavigator.com/ Article/2015/03/10/New-dawn-for-gasto-feed-protein-as-Calysta-flags-up-2017production-start-date, 2021

[39] Initial. Calysta, "Cargill officially break ground on NouriTech, a new feed production plant in Memphis," (year), https://www.cargill. com/2017/calysta-cargill-officially-breakground-on-nouritech-in-memphis 2021

[40] "BP invests in turning natural gas into fish food," (year) https://www.chron.com/business/ energy/article/BP-invests-in-turning-naturalgas-into-fish-food-14054121.php, 2021

[41] "Adisseo and Calysta's world-leading alternative protein joint venture breaks ground in China," https://www.calysta.com/adisseo-and-calystasworld-leading-alternative-protein-jointventure-breaks-ground-in-china/,2021

[42] J.Nielsen, J. Villadsen, and G. Liden, Bioreaction Engineering Principles, Kluwer Academic/ Plenum Publishers, 2003.

[43] T. Storebakken, G. M. Berge, G. Baeverfjord, and A. Skrede, "Bacterial protein grown on natural gas as protein source in diets for Atlantic salmon, Salmo salar, in freshwater, " Aquaculture Is the name of the Journal, vol. 244, pp. 233-240, 2014.

[44] H. Schøven, B. Svihus, T. Storebakken, and A. Skrede, "Bacterial protein meal produced on natural gas replacing soybean meal or fish meal in broiler chicken diets," Archives of Animal Nutrition, vol. 61, pp. 276-291, 2007.

[45] CALYSTA, "Commercialization of new proteins: Feedkind protein," BIO World Congress, Montreal, 2017.

[46] M. Tlusty et al., "A transdisciplinary approach to the initial validation of a single cell protein as an alternative protein source for use in quafeeds." Peer J., 5:e3170, 2017, https://doi.org/10.7717/ peerj.3170 , 2021

[47] https://www.unibio.dk/end-product/aminoacid-profile/ , 2021

[48] H. Eriksen, K. Strand, and L. Jorgenson, "Method of fermentation," US Patent US 2009/0263877 A1., 2009, https://patents.google.com/patent/ US20090263877/, 2021

[49] E.B. Larsen, "U-shape and/or nozzle u-loop fermentor and method of carrying out a fermentation process," US Patent 6492135, 
$2002 . \quad$ https://patents.google.com/patent/ WO2010069313A2/, 2021

[50] F.Yazdian,S.Shojaosadati,M.Nosrati,M.Mehrina, "Comparison of different loop bioreactors based on hydrodynamic characteristics, mass transfer, energy consumption and biomass production from natural gas." Iran. J. Chem. Chem. Eng., vol. 29, pp. 37-56, 2010.

[51] D.F. Olsen, J. B. Jorgensen, J. Villadsen, and S. B. Jorgensen, "Optimal operating points for SCP production in the U-loop reactor," in Proceedings of the 9th International Symposium on Dynamics and Control of Process Systems (DYCOPS '10), M. Kothare, M. Tade, A. Vande Wouwer, and I. Smets, Eds., Belgium, 2010.

[52] A.M. Al Taweel, Q. Shah, and B. Aufderheide, "Effect of mixing on microorganism growth in loop bioreactors," Intern. J. Chem. Eng., Article ID 984827, doi:10.1155/2012/984827, 2012

[53] Q. Shah, B. Aufderheide, and A.M. Al Taweel, "Developing cost-effective processes for converting natural gas into single cell protein," Comp. Aided Chem. Eng., 30 , 537-541, 2012.

[54] A. Petersen, L.A.H complete the family name., J. Villadsen, S.B. Jørgensen, and K.V. Gernaey, "Mixing and mass transfer in a pilot scale U-loop bioreactor," Biotechnol. Bioeng, vol. 114, pp. 344-354, 2017.

[55] A.M. Al Taweel, Converting Natural Gas to Animal Feed- A Profitability Analysis (unpublished Report), 2010.

[56] T. Cumberlege, T. Blenkinsopp, J. Clark, "Assessment of environmental impact of FeedKind protein," Carbon Trust, 2016, https:// www.carbontrust.com/resources/assessmentof-environmental-footprint-of-feedkindprotein publication data, 2021

[57] G. Rychen et al., "EFSA panel on additives and products or substances used in animal feed," Guidance on the Characterisation of Microorganisms Used as Feed Additives or as Production Organisms. EFSA J. vol. 16, pp. 5206, 2018.

[58] J.P.M. Sanders et al., "Process intensification in the future production of base chemicals from biomass," Chem. Eng. Proc., vol. 51, pp. 117-136,
2012.

[59] H.J. Noorman, W. van Windena, J. J. Heijnenb, and R. G. J. M. van der Lans, 2018, "Intensified fermentation processes and equipment," in Intensification of Biobased Processes, A. Górak and A. Stankiewicz, Eds., The Royal Society of Chemistry, Published by the Royal Society of Chemistry, www.rsc.org,

[60] G. Li et al., "Hydrodynamics, mass transfer and cell growth characteristics in a novel microbubble stirred bioreactor employing sintered porous metal plate impeller as gas sparger," Chem. Eng. Sci., vol. 192, pp. 665-677, 2018.

[61] F.J. Keil, 2018, "Process intensification," Rev. Chem. Eng., vol. 34, pp,135-200, 2018.

[62] L.A.M. van der Wielen, I. Solange, C. Mussatto, and J. van Breugel,"Bioprocess intensification: Cases that (don't) work," New Biotech., vol. 61, pp. $108-115,2021$.

[63] M.M. El-Halwagi, "Sustainable design through process integration: fundamentals and applications to industrial pollution prevention, resource conservation, and profitability, Butterworth-Heinemann, ISBN, 978-1-85617744-3, 2017

[64] L.C. Nhien, N. van DucLong, and M. Lee, "Novel heat-integrated and intensified biorefinery process for cellulosic ethanol production from lignocellulosic biomass," Energy Conv. Manag., vol. 141, pp. 367-377, 2017.

[65] B.V. Ayodele, M.A. Alsaffar, S.I. Mustapa, "An overview of integration opportunities for sustainable bioethanol production from firstand second-generation sugar-based feedstocks," J. Cleaner Production, vol. 245, 118857, 2020.

[66] R. Kapoor et al., "Advances in biogas valorization and utilization systems: A comprehensive review," J. of Cleaner Production, vol. 273, pp. $123052,2020$.

[67] M. Springmann, M. Clark, D. Mason D'Croz et al.," Options for keeping the food system within environmental limits," Nature, vol. 562, pp. 519525, 2018. 